\title{
Effect of Date Palm Pollen and Bee Pollen as Growth Promoters on the Performance of Saidi Rams
}

\author{
Taghian, Raghda A.S.; M.N. Abd El-Ati; F.M. Allam and G.B. Mahmoud
}

Animal Production Department, Faculty of Agriculture, Assiut University, Assiut, Egypt

Received on: $21 / 8 / 2017$

Accepted for publication on: 28/8/2017

\section{Summary}

The experiment was conducted at the Animal Experimental Farm, Animal Production Department, Faculty of Agriculture, Assiut University, Assiut, Egypt. The aim of this study was to determine body performance of rams drenched three times weekly for three months with: tab water (Control, C), date palm pollen (DPP) $30 \mathrm{gm}$, bee pollen (BP) $30 \mathrm{gm}$, and artificial bee bread (BB) $30 \mathrm{gm}$. All experimental supplements suspended in tab water.

Twenty Saidi rams were assigned randomly to four treatment groups $(\mathrm{C}$, DPP, BP and BB) with an average initial body weight, 35.00, 36.24, 36.74 and $35.68 \mathrm{~kg}$, respectively. Animals were fed roughage and concentrate dietsad libitum during the experimental period (three months). Feed consumption was determined, live weight gain and feed conversion were calculated. At the end of experimental period, the final body weight in C and DPP, BP and BB treated groups was $44.38,52.75,53.13$, and $58.38 \mathrm{~kg}$, respectively. Regarding body weight $(\mathrm{BW})$ and average daily gain DPP, BP and BB showed significant increase $(\mathrm{P}<0.05)$ than the control while $\mathrm{BB}$ significantly $(\mathrm{P}<0.05)$ exceeded the other two treatments DPP and BP. No significant differences were detected between DPP and BP treated groups. All treated rams had higher $(\mathrm{P}<0.05)$ total feed intake than the control. Feed conversion of DPP, BP and BB treated rams improved and was significantly lower $(\mathrm{P}<0.05)$ than the control. While the $\mathrm{BB}$ treated rams group showed the lowest feed conservation rate.

Keywords: Date palm pollen, bee pollen, bee bread, sheep.

\section{Introduction}

The use of antibiotics in animal nutrition has been prohibited in the European Union since January 2006 (Oeztuerk and Sagmanligil 2009). This trend has powered interest in natural nutritional concepts. Phytogenic feed additives may be included among supplements that are aimed to positively affect feed quality, health of animals as well as animal products by means of their specifically efficacious substances (Karásková et al. 2015).

The ancient Egyptians described pollen as "a life-giving dust". Pollen of the date palm (DPP) has been used for thousands of years as a traditional Egyptian herbal medicine for improving male and female fertility (Soliman and Soliman, 1957 and Amin et al., 1969). Phytochemical studies of DPP showed the presence of estrone, $\alpha$-amirin, triterpenoidalsaponins, estradiol and estriol five flavonoids and a crude gonadotrophic substance (Mahran et al., 1985 and Abbas and Ateya, 2011). In addition, palm pollen was found to strengthen and increase the resistance of different tissues to different harmful pathogens and toxicants due to their high pheno- 
lic and flavonoid contents (Campos et al., 1997).

Bee pollen (BP) is aggregate of flower pollen composed from several plant sources by honeybees by collecting millions of floral pollen grains and mixing it with plant nectar and bee saliva rich in enzymes thus altering its composition and improving its therapeutically potential (Leblanc et al., 2009). It is a substantial source of proteins (25-30\%), lipids, including fatty acids and sterols, rich source of free amino acids; more than 12 vitamins, 28 minerals, 59 trace elements, 11 enzymes or coenzymes, carbohydrates $(35-65 \%)$, which are chiefly glucose, fructose and sucrose, as well as antibiotic substances, antioxidant substances, carotenoids, polyphenolics such as flavonoids and carbohydrates (Xu et al., 2009, Attia et al., 2011b and Haščík, et al., 2012). Furthermore, Hajkova, et al. (2013) indicated that bee pollen contains a noticeable source of compounds with health protective potential and antioxidant activity.

Correspondingly, amino acids, vitamins and trace elements of BP are nutritionally beneficial for improving intestinal absorptiondue the stimulation the development, proliferation and differentiation of intestinal cells and because they improve the environmental conditions for the intestinal microbial ecosystem. BP could also improve the cell immune response, the antibody production speed, and reinforce the immunological system (Song et al., 2005). BP composition tend to be speciesspecific and has been related to the therapeutic properties (antibiotic, antifungal, antineoplasic, antidiarrhoeic and antioxidant) of pollen (AlmarazAbarca et al., 2004 and Hajkova, et. al., 2013). Attia et al. (2011a and 2014a and Battaa and El-Kholy 2014) reported that bee pollen increased body weight gain and survival rate and reduced feed intake and feed conversion ratio of offspring up to 12 weeks of age. Khojasteh and Shivazad (2006) and Wang et al. (2007) stated that BP contains digestive enzymes from the bees.

However, Rimpler (2003) hypothesized that BP was insufficiently digested and that cracking would improve the digestibility and bioavailability. Regarding to natural beebread (BB), to feed its larvae bees store pollen in the hive as beebread. Pollen is mixed with honey and bee secretions and stored in the combs. Bee bread undergoes a lactic acid fermentation and can be thus preserved. This improves the nutritional value of pollen grains. Beebread is an excellent source of otherwise scarcely available nutrients and produced in a very small amount (Krell, 1996). There is no information about the effect of DPP, BP and BB on body performance of ruminants especially in sheep. There are no previous reports dealing with artificial bee bread (BB) as growth promoter in farm animals or poultry. Therefore, the present study was aimed at elucidating the effects of supplementing DPP, BP and BB productive performance in Saidi rams.

\section{Materials and Methods}

The experiment was conducted at the Animal Experimental Farm, Animal Production Department, Faculty of Agriculture, Assiut University, Assiut, Egypt. Fresh commercial 
date palm pollens (DPP) were bought at the season of date palm male tree flowering. Fresh commercial multifloral bee pollens (BP) were used.

Artificial bee bread (BB) was prepared according to modified method after Dany, (1988). The natural bee bread was more or less simulated artificially using date palm pollen (DPP), honey, Lactobacillus bulgaricus and Streptococcus thermophiles (10 shares of pollen: 1.5 shares of honey: 2.5 shares of clean water, in shares by weight, and small quantity of lactic acid bacteria). The temperature for the first 2-3 days was between 32 and $34^{\circ} \mathrm{C}$. After that, the temperature was lowered to $20-24^{\circ} \mathrm{C}$ for about one week.

Twenty Saidi rams of about 35$36 \mathrm{~kg}$ body weight were assigned randomly to four treatment groups (C, DPP, BP and BB) with an average body weight, 35.00, 36.24, 36.74 and $35.68 \mathrm{~kg}$, respectively. The control group (C) was drenched tap water while DPP, BP and BB treated groups were drenched $30 \mathrm{~g}$. of watersuspended date palm pollens (DPP), bee pollens (BP), or artificial bee bread (BB). Rams were drenched three times weekly for the three months of the experimental period.

Animals were fed roughage and concentrate diet ad libitum during the experimental period. Animals were weighed at the beginning of the experiment in the morning before feeding and biweekly thereafter to determine body weight. Feed consumption was determined, live weight gain and feed conversion ( $\mathrm{kg}$ feed / $\mathrm{kg}$ gain) were calculated.

\section{Statistical analysis:}

Data were statistically analyzed using general linear model (G.L.M.) procedure of SAS (2012). For growth performance, metabolite constituents, the following model was used:

$\mathrm{YijK}=\mathrm{u}+\mathrm{Ti}+\mathrm{Pj}+(\mathrm{TP}) \mathrm{ij}+$ EijK. Where;

Tijk $=$ The observation

$\mathrm{u}=$ general mean

$\mathrm{Ti}=$ Effect due to treatments

$\mathrm{Pj}=$ Effect due to period.

TPij = Effect due to interaction of treatment and period

Eijk $=$ The errors related to individual observation.

\section{Results and Discussion \\ 1-Body weight (BW)}

The mean values and standard error of the effects of DPP, BPand BBon body weight are presented in Table 1. While, Table 4 shows the effects of supplementation with DPP, $\mathrm{BP}$ and $\mathrm{BB}$ on $\mathrm{BW}$.

Mean values of body weight increased $(\mathrm{P}<0.05)$ gradually during the three months of the experimental period among the four experimental groups. Mean values of DPP, BP and $\mathrm{BB}$ showed increase $(\mathrm{P}<0.05)$ in $\mathrm{BW}$ than the control treatment while $\mathrm{BB}$ significantly $(\mathrm{P}<0.05)$ exceeded the other two treatments (DPP and BP). No significant differences have been detected between DPP and BP treated groups (Table 1). 
Table 1. Live body weight (Kg) of rams supplemented with DPP, BP and BB.

\begin{tabular}{|c|c|c|c|c|}
\hline \multirow{2}{*}{ Treatments } & \multicolumn{3}{|c|}{ Month } & \multirow{2}{*}{ Mean } \\
\hline & 1 & 2 & 3 & \\
\hline $\mathrm{C}$ & $38.00 \pm 1.01$ & $41.75 \pm 1.71$ & $44.38 \pm 1.94$ & $41.38^{C} \pm 1.10$ \\
\hline DPP & $41.75 \pm 0.75$ & $48.00 \pm 0.96$ & $52.75 \pm 2.04$ & $47.50^{\mathrm{B}} \pm 1.41$ \\
\hline $\mathrm{BP}$ & $40.55 \pm 0.88$ & $46.50 \pm 1.06$ & $53.13 \pm 2.19$ & $46.71^{\mathrm{B}} \pm 1.59$ \\
\hline $\mathrm{BB}$ & $43.50 \pm 0.96$ & $51.25 \pm 0.46$ & $58.38 \pm 0.66$ & $51.04^{\mathrm{A}} \pm 1.67$ \\
\hline Mean & $40.94^{\mathrm{c}} \pm 0.62$ & $46.88^{\mathrm{b}} \pm 0.94$ & $52.16^{\mathrm{a}} \pm 1.42$ & \\
\hline L.S.D.0.05 & \multicolumn{3}{|c|}{1.66} & $\begin{array}{ll}\text { L.S.D. } & \\
& \\
\end{array}$ \\
\hline
\end{tabular}

\section{2- Daily weight gain:}

The mean values and standard error of the effects of the growth promoters (DPP, BP and BB) on body weight gain (g/day) are presented in Table 2. While, Table 4 shows the effects of supplementation with DPP, BP and BB on daily weight gain. Significant differences $(\mathrm{P}<0.05)$ in mean values of BW Gamong the four experimental groups were observed (103.11, 182.33 179.84 , and $259.11 \mathrm{~g} /$ day for the con- trol, DPP, BP and BB treatments, respectively). Mean values of DPP, BP and $\mathrm{BB}$ showed significant $(\mathrm{P}<0.05)$ increase than the control one, while the $\mathrm{BB}$ group significantly $(\mathrm{P}<0.05)$ exceeded the other two treatments DPP and BP. No significant differences have been detected between DPP and BP groups (Table2). Insignificant differences were detected among the three months of the experimental period, over all the four treatments (Table 2).

Table 2. Daily weight gain (g/d) of rams supplemented with DPP, BP and BB.

\begin{tabular}{|c|c|c|c|c|}
\hline \multirow{2}{*}{ Treatments } & \multicolumn{3}{|c|}{ Month } & \multirow{2}{*}{ Mean } \\
\cline { 2 - 4 } & 1 & 2 & 3 & \\
\hline C & $90.00 \pm 16.33$ & $131.34 \pm 19.11$ & $114.67 \pm 13.69$ & $103.11^{\mathrm{C}} \pm 11.37$ \\
\hline DPP & $177.34 \pm 10.92$ & $205.33 \pm 8.60$ & $164.67 \pm 17.50$ & $182.33^{\mathrm{B}} \pm 12.66$ \\
\hline PB & $160.67 \pm 28.90$ & $173.34 \pm 19.44$ & $206.67 \pm 43.01$ & $179.84^{\mathrm{B}} \pm 24.92$ \\
\hline BB & $284.00 \pm 32.07$ & $253.34 \pm 22.61$ & $236.67 \pm 25.49$ & $259.11^{\mathrm{A}} \pm 15.78$ \\
\hline Mean & $173.25 \pm 19.29$ & $197.50 \pm 13.31$ & $172.54 \pm 6.78$ & \\
\hline L.S.D. ${ }_{0.05}$ & 41.78 & L.S.D. ${ }_{0.05} 48.24$ \\
\hline
\end{tabular}

The present study showed that rams fed diets with $\mathrm{DPP}, \mathrm{BP}$ and $\mathrm{BB}$ at $30 \mathrm{~g}$ /day three times/weekly had improved live body weight and daily gain. Our findings are in agreement with those of previous reports with other farm animals. For example, Dietary pollen improved growth performance, survival rate, egg productivity, feed utilization efficiency, immunity, and resistance to diseases in chickens. Similar effects were also observed in pigs, as supplementary BP stimulated growth rates of swine (Huai et al. 2005).

The positive effect of DPP, BP and $\mathrm{BB}$ administration on $\mathrm{BW}$ and BWG can be attributed to the presence of a lot of nutrient factors (as antioxidants, vitamins, mineral, essential fatty acids, vitamins, amino acids, enzymes etc.) and protective 
agents, such as flavonoids, carotenoids, and phenolic constituents in the BP which can improve nutrient value of the feed as well as feed digestibility and absorption (Leja et al., 2007; Saric et al., 2009). Wang and Cheng (2005) assessed the presence of $\mathrm{BP}(1,2,3,4$ and $5 \%)$ indiets for growing and finishing pigs and reported that the 4 and 5\% levels improved the daily weight gain of the animals. Similarly, the improvement of intestinal mucosa morphology in rabbits supplemented by BP may be partially responsible for the higher growth rate obtained in the current study. However, pollen feeding in mammals increased the intestinal absorptive capacity through the longer and thicker villi (Wang et al., 2007).

Bee pollen comprises high concentrations of reducing sugars, essential amino acids and unsaturated/saturated fatty about half of them are the unsaturated acids oleic, linoleic (omega-6) and linolenic (omega-3), minerals as $\mathrm{Zn}, \mathrm{Cu}$, Fe, Se and high $\mathrm{K} / \mathrm{Na}$ ratio. Significant quantities of several vitamins in bee pollen: provitamin A, B complex, A, C, D, K3, E (tocopherol), vitamin B2 (riboflavin), niacin, thiamine, folic acid was observed and biotin has an important role in metabolism of proteins, fats and carbohydrates and has participation in vitamins B6, B9 and B12 metabolism which reflected in an enhanced animal performance. It is also a potential source of polyphenols and other healthy compounds (Santos Pereira, et al., 2010, Campos, et al., 2010 and Attia et.al. (2014 a).

The effects of BP can be also attributed to the factthat BP is an energy enhancer, a growth promoter, and a potential antibiotic (AlmarazAbarca et al. 2004). The nourishing and medical beneficial of BP as an antioxidant, anti-aging substance, and a supplement to improve immune function and growth in animals have been widely appreciated (AlmarazAbarca et al. 2004 and Battaa and ElKholy 2014).

An earlier study proposed that supplementation BP at $1.5 \%$ of diet improved the organizational structure of the digestive tract of layer hens, thus enhancing digestion and absorption (Wang et al. 2006). Broiler diets supplemented with $1.5 \%$ BP promoted the early development of the intestine, enhanced the immune function, and promoted the development of the liver, pancreas, and small intestine which reflected in an enhanced animal performance. (Song et al. 2005).

It is important to point out that, the use of $\mathrm{BB}$ as an additive for rams or other species has not been reported. However, Rimpler (2003) hypothesized that BP was insufficiently digested and that cracking would improve the digestibility and bioavailability. Taking this hypothesis in consideration, in this investigation it may plausibly explain the superiority of artificial BB compared to both DPP and $\mathrm{BP}$ in increasing live body weight in the present research. Lactic acid fermentation of DPP by Lactobacillus bulgaricus and Streptococcus thermophiles which in the presence of honey produce lactic acid consequently it digests the pollen walls and release all component of the pollens. The renders end product $(\mathrm{BB})$ is more digestible and enriched with new nutrients. It is interesting to point out 
that bees used $\mathrm{BB}$ alone to feed its larvae. Supplementary researches showed that BP improved the small intestine absorption areas, promoted the development of lymphoid tissue, and enhanced the digestion and immune function of piglets (Wang et al. 2004).

Also, the improvement of intestinal mucosa morphology in rabbits supplemented by BP may be partially responsible for the higher growth rate. However, pollen feeding in mammals increased the intestinal absorptive capacity through the longer and thicker villi (Wang et al., 2007).

However, as this a pilot study dealing with the application of DPP and BP on sheep for the first time and the pioneer usage of artificial $\mathrm{BB}$ on either farm animals or poultry, additional studies should be conducted to precisely determinate the proper application, the level of the treatments, the proper animal age, the effects of the treatments on both sexes, the effects of treatments at maturity and its consequences on the progeny, the op- timal supplementation level of the treatment etc. The lower dose may be insufficient, and over dose can exhibit adversative effects. Future researches are needed to clarify the effects of treatment with DPP, BP and $\mathrm{BB}$ or its polysaccharides on the organizational structure of the digestive tract of rams.

\section{3-Total feed intake:}

The mean values and standard error of the DPP, BP and BB on total feed intake in $\mathrm{kg} /$ day are presented in Table 3. While, Table 4 shows the effects of supplementation with DPP, $\mathrm{BP}$ and $\mathrm{BB}$ on daily feed intake.

During the experimental period, mean values of total feed intake increased significantly $(\mathrm{P}<0.05)$ in the $2^{\text {nd }}$ and $3^{\text {rd }}$ months than the $1^{\text {st }}$ month. Total feed intake increased significantly $(\mathrm{P}<0.05)$ in the three groups of rams (DPP, $\mathrm{BP}$, and $\mathrm{BB}$ ) than the control group. Nonsignificant differences between the three DPP, BP, and $\mathrm{BB}$ supplemented groupsas shown in Table (3).

Table 3. Total feed intake of rams supplemented with DPP, BP and BB.

\begin{tabular}{|c|c|c|c|c|}
\hline \multirow{2}{*}{ Treatments } & \multicolumn{3}{|c|}{ Month } & \multirow{2}{*}{ Mean } \\
\hline & 1 & 2 & 3 & \\
\hline $\mathrm{C}$ & $0.99 \pm 0.02$ & $1.1 \pm 0.02$ & $0.89 \pm 0.02$ & $0.99^{D} \pm 0.04$ \\
\hline DPP & $1.05 \pm 0.01$ & $1.34 \pm 0.01$ & $1.38 \pm 0.02$ & $1.26^{\mathrm{B}} \pm 0.04$ \\
\hline $\mathrm{BP}$ & $1.09 \pm 0.04$ & $1.23 \pm 0.10$ & $1.16 \pm 0.06$ & $1.16^{\mathrm{C}} \pm 0.06$ \\
\hline BB & $1.19 \pm 0.02$ & $1.36 \pm 0.02$ & $1.44 \pm 0.01$ & $1.33^{\mathrm{A}} \pm 0.04$ \\
\hline Mean & $1.08^{\mathrm{c}} \pm 0.03$ & $1.26^{\mathrm{a}} \pm 0.04$ & $1.21^{\mathrm{b}} \pm 0.06$ & \\
\hline \multicolumn{4}{|l|}{ L.S.D.0.05 } & L.S.D. ${ }_{0.05} 0.11$ \\
\hline
\end{tabular}


Table 4. Daily feed intake (DFI), growth performance and feed conversion (FCR) of rams supplemented with DPP, BP and BB

\begin{tabular}{|c|c|c|c|c|}
\hline \multirow{2}{*}{ ITEM } & \multicolumn{4}{|c|}{ Growth Promoter } \\
\hline & CONTROL & DPP & $\mathbf{B P}$ & BB \\
\hline Total feed intake $\mathrm{Kg}$ /day & $1.11^{\mathrm{c}} \pm 0.05$ & $1.32^{\mathrm{b}} \pm 0.04$ & $1.27^{\mathrm{c}} \pm 0.05$ & $1.38^{\mathrm{a}} \pm 0.06$ \\
\hline Growth performance: & & & & \\
\hline Initial body weight, $\mathrm{Kg}$ & $35 \pm 1.5$ & $36.24 \pm 2.01$ & $35.74 \pm 1.15$ & $35.68 \pm 1.22$ \\
\hline Final body weight, $\mathrm{Kg}$ & $44.38^{\mathrm{c}} \pm 1.91$ & $52.75^{b} \pm 2.04$ & $53.13^{\mathrm{b}} \pm 2.19$ & $58.38^{\mathrm{A}} \pm 0.66$ \\
\hline Daily gain, g/day & $103.11^{\mathrm{b}} \pm 9.93$ & $182.33^{\mathrm{a}} \pm 7.39$ & $179.84^{\mathrm{a}} \pm 17.85$ & $259.11^{\mathrm{c}} \pm 15.36$ \\
\hline FCR Kg feed/Kg gain & $10.65^{\mathrm{a}} \pm 0.82$ & $7.20^{\mathrm{b}} \pm 0.30$ & $6.57^{\mathrm{b}} \pm 0.49$ & $5.47^{\mathrm{c}} \pm 0.16$ \\
\hline
\end{tabular}

These results are in coinciding with those of Da Silva et al. (2014) who reported that the rams fed diets with crude propolis had higher feed intake than those fed diets containing monensin sodium. Also, Tuner et al. (2006) concluded that BP supplementation may help the horse to meet those needs through increased feed intake, and thereby increased nutrient retention.

In this context, BP is reported to evoke an increase in feed intake, Haščík et al. (2012) reported that bee-pollen increased feed intake of broiler chickens in comparison to the control group. Furthermore, Kazem et al. (2016) indicated that the highest body weight, average daily gain, average daily feed intake, carcass weight, and carcass yield were observed in broilers offered 800 mg kg- 1 of bee glue. In this approach, Hosseini et al. (2016) estimated that dietary BP and BG (bee glue) improved average daily gain and average daily feed intake of broilers particularly during the starter period. Similar conclusion was reported by Sakine et al. (2016) in mixed-sex Japanese quail. In 2015 Valero et al. stated that feed intake was higher $(\mathrm{P}<0.05)$ for bulls fed on control $(9.17 \mathrm{~kg} /$ day $)$ and propolis $(9.31$ $\mathrm{kg} /$ day) diets than bulls fed on monensin.

Contrasting to this results Valero et al. (2014) found that the addition of propolis and essential oils in the diets of bulls finished in feedlot improve animal performance and carcass weight but the feed intake was unaffected by the additives addition. In rabbits, Attia et al. (2011a and 2015) demonstrated that feed intake linearly decreased with increasing bee pollen level up to $200 \mathrm{mg}(\mathrm{p}<0.01)$. Further increase in bee pollen $(300 \mathrm{mg} / \mathrm{kg})$ significantly increased feed intake compared to 100 and $200 \mathrm{mg}$. The decrease of feed intake in rabbit fed bee pollen could be explained by the increase in nutrient supply: in fact, nutrients such as minerals and water-soluble vitamins could accelerate nutrients metabolism and increase energy digestibility this, negatively affects feed intake (Attia et al., 2011a). While, Battaa and El-Kholy (2014) showed that treated growing male rabbits with 
bee pollen (BP) caused to decrease in feed intake and improved in feed conversion compared with untreated during experimental period.

\section{1- Feed conversion:}

The mean values and standard error of the effects of control, DPP, $\mathrm{BP}$ and $\mathrm{BB}$ on feed conversion rate are presented in Table5. The three experimental groups that received DPP, BP and BB had significantly $(\mathrm{P}<0.05)$ improved lower FCR in comparison with the control group. Meanwhile, the rams group that received BB showed significantly $(\mathrm{P}<0.05)$ lower FCR than DPP and BP groups as shown in Table 5 . Nonsignificant differences in FCR had been observed between DPP and BP treated groups. Similarly, insignificant differences in FCRhad been detected between the three months of the experimental period (Table 5).

Table 5. feed conversion rate of rams supplemented with DPP, BP and BB.

\begin{tabular}{|c|c|c|c|c|}
\hline \multirow{2}{*}{ Treatments } & \multicolumn{3}{|c|}{ Month } & \multirow{2}{*}{ Mean } \\
\hline & 1 & 2 & 3 & \\
\hline $\mathrm{C}$ & $16.74 \pm 2.09$ & $16.48 \pm 4.92$ & $15.116 \pm 4.44$ & $10.65^{\mathrm{A}} \pm 0.82$ \\
\hline DPP & $10.31 \pm 2.027$ & $8.85 \pm 1.90$ & $12.418 \pm 1.72$ & $7.20^{B} \pm 0.30$ \\
\hline PB & $11.19 \pm 3.32$ & $11.83 \pm 3.76$ & $6.09 \pm 0.98$ & $6.57^{\mathrm{B}} \pm 0.49$ \\
\hline BB & $7.43 \pm 1.62$ & $7.57 \pm 0.61$ & $8.206 \pm 1.01$ & $5.47^{C} \pm 0.16$ \\
\hline Mean & $7.52 \pm 0.53$ & $7.43 \pm 0.61$ & $7.46 \pm 0.71$ & \\
\hline L.S.D ${ }_{0.05}$ & & & & L.S.D ${ }_{0.05} 1.53$ \\
\hline
\end{tabular}

Improving the FCR by treating with phytogenic growth regulators have been reported by several investigators, Zawadzki et al. (2011) studied the performance of feedlotfinished bulls, and reported that the addition of propolis extract to the diet increased weight gain and improved feed conversion. In rabbits, Attia et al. (2011a, 2011b and 2014a) stated that bee pollen at $200 \mathrm{mg} / \mathrm{kg}$ reduced feed conversion ratio of offspring up to 12 weeks of age. Growth and FCR of kits from the treated does during $4-8$ weeks of age were significantly better than growth of kits from control. Bee pollen if in combination with propolis, could be used as a supplement in the growing rabbits with positive effects on growth rate and FCR. Battaa and El-Kholy (2014) showed that treated growing male rabbits with bee pollen (BP) caused to increase significantly in final body weight and weight gain and to decrease in feed intake and improved in FCR compared with the control.

Similar results were observed by El-Hanoun et al. (2007) who found that feed efficiency was improved of growing NZW rabbits supplemented with 250 and $500 \mathrm{mg}$ BP per kg BW compared to the control group during winter and summer seasons from weaning till mature age. Wang and Cheng (2005) evaluated the inclusion of BP $(1,2,3,4$ and $5 \%$ ) in diets for growing and finishing pigs and reported that the 4 and $5 \%$ levels improved the FCR of the animals. In this regard Shewika (2009) and Attia, et al. (2014b) re- 
ported that BP improved growth and FCR of rabbits. These improvements in FCR and lower feed intake may be attributed to BP in decreasing count of pathogenic bacteria and increasing digestion of all nutrients.

The enhancement in growth performance resulted from the addition of BP could be due to the better absorption of amino acids or/and due to antibacterial properties and enzymes or coenzymes of BP. Also, the improvement of digestive enzyme activity and intestinal mucosa morphology in rabbits supplemented by BP may be partially responsible for the higher growth rate obtained in the present study.

It appears from the present study that the addition of growth promoters (DPP, BP and BB) had improved life body weight, daily weight gain, feed intake and feed conversation. However, the treatment with $\mathrm{BB}$ was more effective than other treatments.

\section{References}

Abbas, A. F. and Ateya, A. M. (2011). Estradiol, esteriol, estrone and novel flavonids from date palm pollen. Australian Journal of Basic and Applied Sciences, 5(8): 606614.

Almaraz-Abarca，N.; Campos，M. G.; Avila-Reyes, J. A.; NaranjoJimenez, N.; Herrera-Corral, J. and Gonzalez-Valdez, L. S. (2004). Variability of antioxidant activity among honeybee-collected pollen of different botanical origin, Interciencia, 29: 574-578.

Amin, E. S.; Awad, O.; Abd el samad, M. and Iskandar, M. N. (1969) Isolation of estrone from moghat roots and from pollen grains of Egyptian date palm. Phytochemistry, 9: 295-300.
Attia, Y. A.; Abd Al-Hamid, A. E.; Ibrahim, M. S.; Al-Harthi, M. A.; Bovera, F. and Elnaggar, A. Sh. (2014a). Productive performance, biochemical and hematological traits of broiler chickens supplemented with propolis, bee pollen, and mannan oligosaccharides continuously or intermittently. Livestock Sci., 164: 87-95.

Attia, Y. A.; Al-Hanoun, A. and Bovera, F. (2011a). Effect of different levels

of bee pollen on performance and blood profile of New Zealand White bucks and growth performance of their offspring during summer and winter months. J. Anim. Physiol. Anim. Nutr., 95: 17-26.

Attia, Y. A.; Al-Hanoun, A.; El-Din, A. E.; Bovera, F. and Shewika, Y. E. (2011b). Effect of bee pollen levels on productive, reproductive and blood traits of NZW rabbits. J. Anim. Physiol. and Anim. Nut., v. 95: 294-303.

Attia, Y. A.; Bovera, F.; EL-Tahawy, W. S.; EL-hanoun, A. M.; AL-harthi, M. A. and Habiba, H. I. (2015). Productive and reproductive performance of rabbits does as affected by bee pollen and/or propolis, inulin and/or mannanoligosaccharides. World Rabbit Sci. 2015, 23: 273-282.

Attia, Y. A.; El-Hanoun A. M.; Bovera, F.; Monastra, G.; El-Tahawy, W. S. and Habiba, H. I. (2013). Growth performance, carcass quality, biochemical and haematological traits and immune response of growing rabbits as affected by different growth promoters. Journal of Animal Physiology and Animal Nutrition ,1-12.

Attia, Y. A.; El-Hanoun, A. M.; Bovera, F.; Monastra, G.; El-Tahawy, W. S. and Habiba, H. I. (2014b). 
Growth performance, carcass quality, biochemical and haematological traits and immune response of growing rabbits as affected by different growth promoters. J. Anim. Physiol. Anim. Nutr., 98: 128-139.

Battaa, A. M. El-Neney and El-Kholy, K. H. (2014). Effect of natural additive (bee pollen) on immunity and productive and reproductive performances in rabbits. Egypt. Poult. Sci. Vol (34) (II): (579-606) (2014).

Baylan, M.; Canogullari, S.; Ayaşan, T. and Copur, G. (2010). Effects of dietary selenium source, storage time and temperature on eggshell internal quality in quail eggs. Biological Trace Element Research, 7 December 2010.

Campos, M. G. R.; Frigerio, C.; Lopes, J. and Bogdanov, S. (2010). What is

the future of Bee-Pollen? J. of ApiProduct and ApiMedical Sci., 2 (4): $131-144$.

Campos, M.G.; Mitchel, K.; Cunha, A. and Markham, K. (1997). A systematic approach to the characterization of bee pollens via their flavonoid/phenolic profiles. Phytochemical Analyses 8, 181-185.

Da Silva, J. A.; Ítavo, C. C. B. F.; Ítavo, L. C. V.; Morais, M. G.; Franco, G. L.; Zeoula, L. M.; and da Silva, N. E.R. (2014). Effects of dietary brown propolis on nutrient intake and digestibility in feedlot lambs R. Bras. Zootec., 43(7):376-381.

Dany, B. (1988). Selbstgemachtesaus Bienenprodukten. Ehrenwirth Verlag, München, 174 pp.

El-Hanoun, A. M.; Hedia, H.; El-Sbeiy, M. S. and Kamel, K. I. (2007). Effect of bee pollen supplementation on some productive, reproductive and biochemical traits of growing male rabbits during winter and summer seasons. $5^{\text {th }}$ Int. Conf. on
Rabbit Prod. in Hot Seasons, Hurghada, Egypt, 4-7 December, 417-433.

Gálik, B., Bíro D.; Šimko, M.; Juráček, M.; Capcarová, M.; Kolesárová, A.; Rolinec, M.; Toman, R. and Kanka, T. (2016). The effect of dietary bee pollen intake on growth performance and biochemical indicators of rats. ACTA VET. BRNO 2016, 85: 099-104

Hajkova, Z.; Toman, R.; Hluchý, S.; Gálik, B.; Bíro, D.; Martiniaková, M.; Omelka, R. and Boboňová, I. (2013). The effect of pollen on the structure of the small intestine in rats after an experimental addition in diet. Anim. Sci. and Bio., 46 (1):232-237.

Haščík, P.; Elimam, I. O. and Garlík, J. (2012). The effect of addition bee pollen to feed mixtures on internal fat of broiler Ross 308 . JMBFS, 2 (1): 246-252.

Hosseini, S. M.; VakiliAzghandi, M.; Ahani, S. and Nourmohammadi, R. (2016). Effect of bee pollen and propolis (bee glue) on growth performance and biomarkers of heat stress in broiler chickens reared under high ambient temperature. Journal of Animal and Feed Sciences, 25, 2016, 45-51.

Huai, W.H.; Wang, Z.C.; and Wang, Q. F. (2005). Effects of bee pollen on growth performance and meat quality of growing-finishing swine. Modern Agricultural Science and Technology 12, 64-65. [In Chinese].

Karásková, K.; Suchý, P.; and Straková, E.(2015). Current use of phytogenic feed additives in animal nutrition - a Review. Czech J Anim Sci 60: 521-530.

Kazem, Z.; Nazar Afzali and Mostafa Rajabzadeh (2016). Effect of bee glue on growth performance and immune response of broiler chick- 
ens, Journal of applied Animal Research,

http://dx.doi.org/10.1080/0971211

9.2016.1174130.

Khojasteh, S.S. and Shivazad, M. (2006). The effect of diet Propolis supplementation on Ross broiler chick's performance. Int. J. Poul. Sci., (5): 84-88.

Krell, R. (1996). Value-added products from beekeeping. Fao Agricultural Services Bulletin No. 124. Chapter 3, pp 94.

Leblanc, B. W.; Davis, O. K.; Boue, S.; Delucca, A. and Deeby, T. (2009). Antioxidant activity of Sonoran Desert bee pollen, Food Chem., 115: 1299-1305.

Leja, M.; Mareczek, A.; Wyzgolik, G.; Klepacz-Baniak, J.; Czekon' ska, K. (2007). Antioxidative properties of bee pollen in selected plant species. Food Chemistry 100, 237240.

Mahran, G. H.; Abdul-Wahab, S.M. and Attia, A.M. (1985). Constituents of the Egyptian Date Palm Pollen: Saponin and Lipid Constituents of Pollen Grains. First Int. Conf. vol. I, Zag. Univ., 30 March - 1 April.

Oeztuerk, H. and Sagmanligil, V., (2009). Role of live yeasts on rumen ecosystem, Deutsche Tierarztliche Wochenschrift, 116, 244248.

Rimpler, M. (2003). Von Bienengesammelte Blütenpollen: Eigenschaften und Verwendung. Ärztezeitschriftfür Naturheilverfahren 44 (3): 158-165.

$\mathrm{S}$ aric', A.; Balog, T.; Soboc'anec, S.; Kus`ic, B.; S`verko, V.; Rusak, G.; Likic, S.; Bubalo, D.; Pinto, B.; Reali, D.; and Marotti, T., (2009). Antioxidant effects of flavonoid from Croatian Cystusincanus $\mathrm{L}$. rich bee pollen. Food and Chemical Toxicology 47, 547554.
Sakine, B.; Shaeban Rahimi; Mohammad Amir KarimiTorshizi; Golamhosein Tahmasebi and Seyed Naser Khaleghi Miran (2016). Effects of propolis, royal jelly, honey and bee pollen on growth performance and immune system of Japanese quails. Veterinary Research Forum. 2016; 7 (1) $13-20$.

SAS Institute.(2012). SAS User's Guide: Statistics. Version 8. SAS Institute Inc, Cary. North Carolina.

Sequeira, J.; Nicodemus, N.; Carabano, R. and Villamide, M.J. (2000). Effect of type of wheat and addition of enzymes on some digestive parameters at different sampling time. Proc. $7^{\text {th }}$ World Rabbit Congress, Valencia, Spain: 437-444.

Shewika, Y. (2009). Influence of different levels of bee pollen on productive

and reproductive performance of New Zealand white rabbits. M.Sc. Faculty of Agric. (Damanhour Branch), Alexandria University.

Soliman, F.A. and Soliman, L. (1957). The gonadotrophic activity of date palm pollen grains. Experientia., 13(10): 411-412.

Song, Y. F.; Wang, J.; Li S.H. and Shang, H.F. (2005). Effects of bee pollen on the development of digestive gland of broilers. Animal Husbandry \& Veterinary Medicine 37, 14-17. [In Chinese].

Tuner, K. K.; Nielsen, B. N.; O'connor, C. I. and Burton, J. L. (2006). Bee pollen product supplementation to horses in training seems to improve

feed intake: a pilot study. J. Anim. Physiol Anim. Nutr. (berl), 90: 414- 420.

Valero, M. V.; Lúcia, M. Z.; Lucimar, P. P. M; João B. G. C. J; Bruna, B. S. and Ivanor, N. P. (2015). Propolis extract in the diet of crossbred $(1 / 2$ 
Angus vs. $1 / 2$ Nellore) bulls finished in feedlot: animal performance, feed efficiency and carcass characteristics. Ciências Agrárias, Londrina, v. 36 , n. 2, p. $1067-$ 1078 .

Wang, J.; Wang, Q. F. and Li, S. H. (2004). Effect of bee pollen on the organizational structure of porcine small intestine of growingfinishing pigs. Journal of Cereal \& Feed Industry 8, 41-42. [In Chinese].

Wang, J. L.; Wang, Q.; Xin, B. and Wang, H. (2007). Trophic effect of bee pollen on small intestine in broiler chickens. J. Med. Food, 10: 276-280.

Wang, J.; Gu, Y. F.; Li, S. H.; Fang, Z. S. and Feng, B. M. (2006). Effect of the bee pollen on histological structure of digestive organs of layer. Journal of AnHui Sciences and Technology University 20, 16. [In Chinese].

Wang, Q. F. and Cheng, Q. F. (2005). Effect of pollen on duodenum configuration and structure of growing-finishing swine. Journal of HuaiHai Institute of Technology 14, 59-62. [Natural Sciences Edition].

Xu, X.; Sun, L.; Dong, J. and Zhang, H. (2009). Breaking the cells of rape bee pollen and consecutive extraction of functional oil with supercritical carbon oxide. Innovative Food Sci. and Emerging Tech., 10: 42-46.

Yan, Tu; Guo-Feng Zhang; Kai-Dong Deng; Nai-Feng Zhang and Qi-Yu Diao (2015). Effects of supplementary bee pollen and its polysaccharides on nutrient digestibility and serum biochemical parameters in Holstein calves.Animal Production Science, 55, 13181323

Zawadzki, F.; Prado, I. N.; Marques, J. A.; Zeoula, L. M.; Rotta, P. P.; Sestari, B. B.; Valero, M. V. and Rivaroli, D. C. (2011). Sodium monensin or propolis extract in the diets of feedlot-fnished bulls: effects on animal performance and carcass characteristics. Journal of Animal and Feed Sciences, 20, 2011, 16-25. 
تأثير حبوب لقاح النخيل وكتل حبوب اللقاح المجمعة بواسطة النحل كمفز للنمو على أداء الحملان

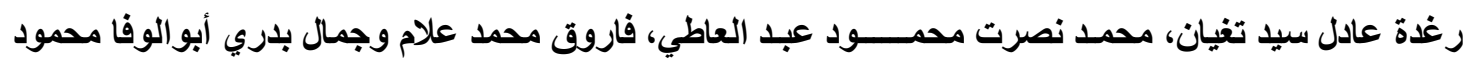
قسم الإنتاج الحيو اني، كلية الزراعة، جامعة أسيوط.

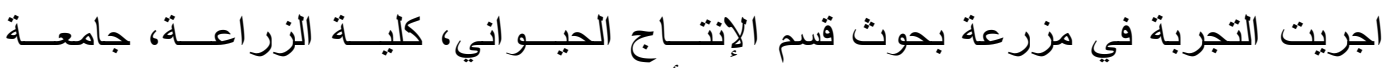

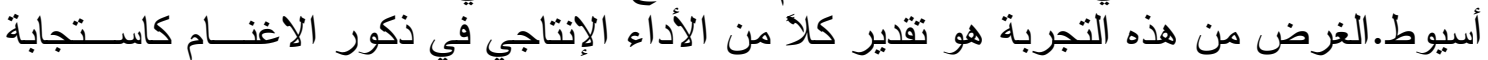

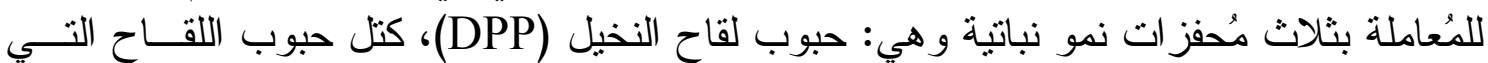

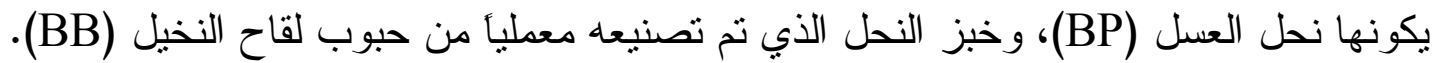

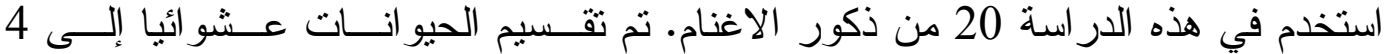

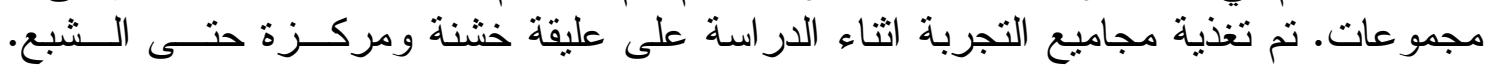

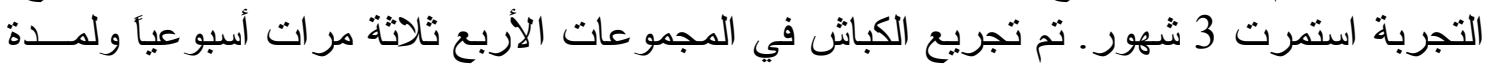

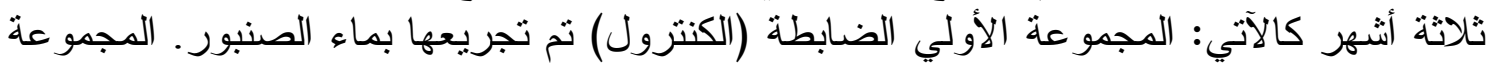

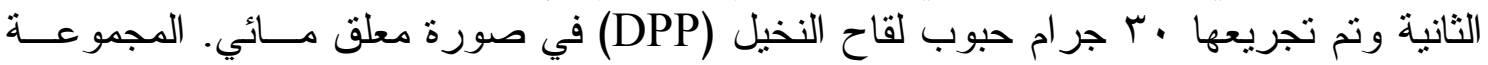

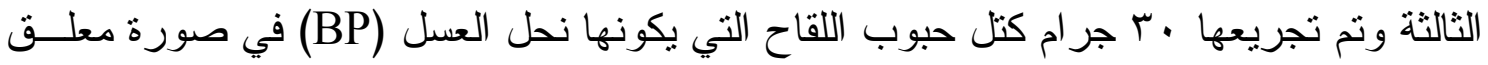

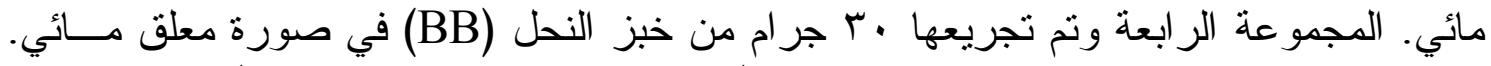

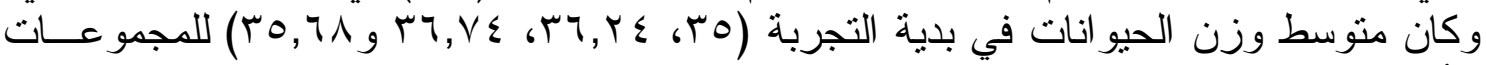

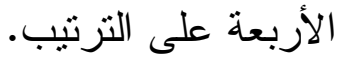

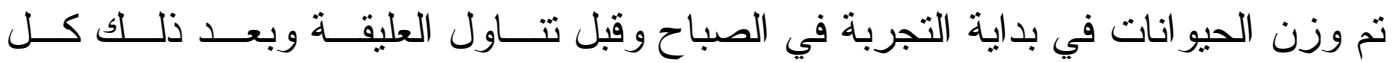

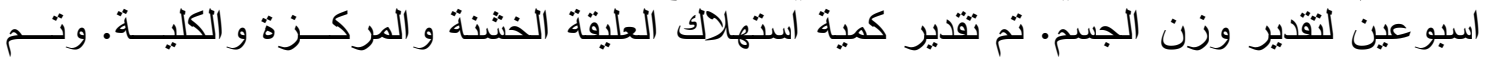

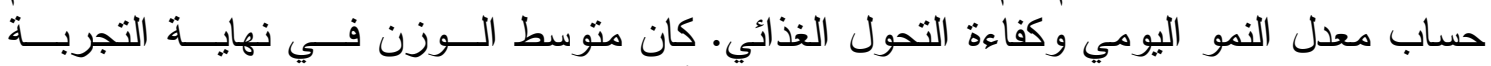

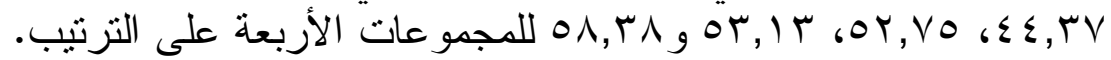
وقد أظهرت الار اسة النتائج الاتية:

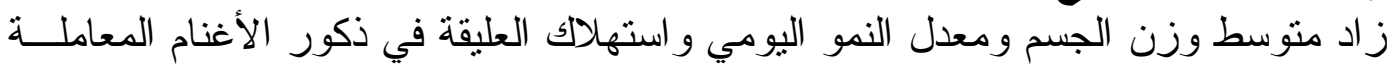

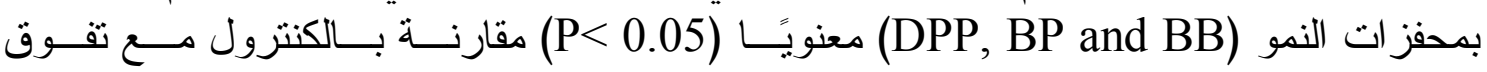

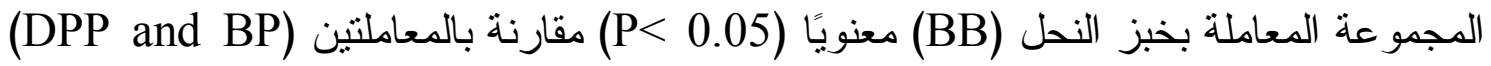

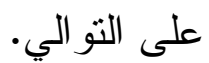

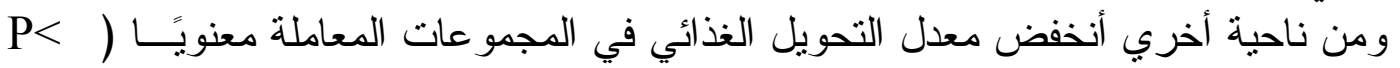

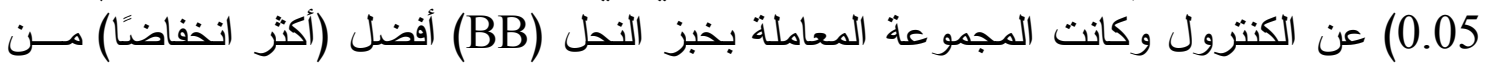
المجموعات الأخرى. 